\title{
Allylic Substitution Reactions with Grignard Reagents Catalyzed by Imidazolium and 4,5-Dihydroimidazolium Carbene-CuCl Complexes
}

Sentaro Okamoto, 'Satoshi Tominaga, Naoko Saino, Kouki Kase, and Kentaro Shimoda

Department of Applied Chemistry, Kanagawa University, 3-27-1 Rokkakubashi, Kanagawa-ku, Yokohama 221-8686, Japan

\begin{abstract}
Imidazolium and 4,5-dihydroimidazolium carbene- $\mathrm{CuCl}$ complexes effectively catalyzed the substitution reaction of allylic compounds with Grignard reagents in an $\mathrm{S}_{\mathrm{N}} 2$ '-selective fashion. It was noteworthy that the amount of the imidazolium carbene- $\mathrm{CuCl}$ complex could be reduced to 0.001 mol\% and the catalysis recorded a high TON $\left(10^{5}\right)$. Based on the experimental results, the ate-type complex(es) such as [(imidazolium carbene) $\left.-\mathrm{CuR}_{2}\right]^{-}(\mathrm{MgX})^{+}$was postulated as an active species .
\end{abstract}

\section{Introduction}

Copper-catalyzed allylic substitution reactions with Grignard reagents have received widespread acceptance as valuable methods for preparation of $\alpha$-substituted alkenes [1,2]. The regioselectivity, stereoselectivity and stereospecificity of the substitution are dependent upon the structure of the substrates and the Grignard reagents and are also influenced by the reaction conditions including copper salt, solvent(s), temperature and the addition order of reagents [1,2]. Investigation has also been focused on enantioselective reactions using copper catalysts with chiral ligands [3]. Recently, we have developed a novel procedure for $\mathrm{S}_{\mathrm{N}} 2$ '-selective reaction with a Grignard reagent which was catalyzed by copper $N$-heterocyclic carbene (NHC)[4] complexes and it has been applied to enantioselective substitution by using chiral modified NHC ligands $[5,6]$. Herein we discuss more detailed features of this catalysis based on experimental results regarding catalytic activities, stoichiometric reactions, stereospecificity and enantioselectivity. 


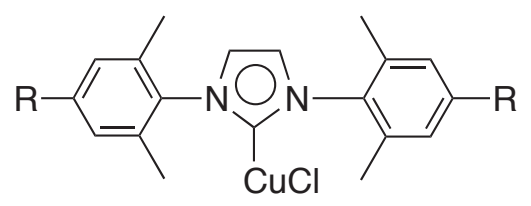

1a: $\mathrm{R}=\mathrm{Me}$

1b: $R=H$

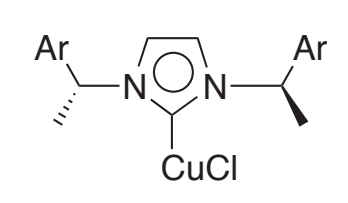

1d: $\mathrm{Ar}=\mathrm{Ph}$

1e: $A r=2$-naphtyl

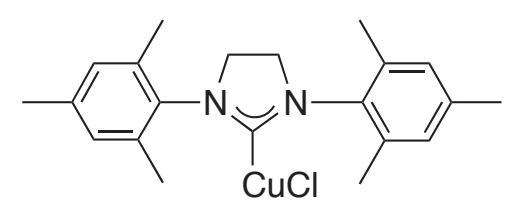

$1 \mathrm{c}$

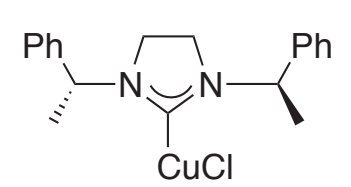

$1 f$

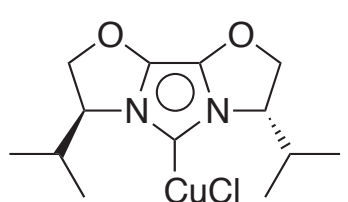

$1 \mathrm{~g}$

Figure 1

\section{Results and Discussion}

\subsection{Catalytic Activity of Imidazolium and 4,5-Dihydroimidazolium Carbene-CuCl complexes}

In a previous paper [7] we described the characteristic features, regarding the structure of allylic substrates and Grignard reagents, and solvent effects, of the NHC-CuCl-catalyzed allylic substitution reaction and found that the reaction was reasonably general: (i) The reaction in ethyl ether proceeded in a highly $\mathrm{S}_{\mathrm{N}} 2$ '-selective fashion (>94:6). (ii) The reaction in THF was relatively slow and an allylic substrate having an ester as a leaving group gave an $\mathrm{S}_{\mathrm{N}} 2$ product mainly but reaction of allylic chloride proceeded $\mathrm{S}_{\mathrm{N}} 2$ '-selectively. (ii) A variety of allylic substrates and Grignard reagents except for aryl magnesium halides could be used and afforded $S_{\mathrm{N}} 2$ '-product predominantly.

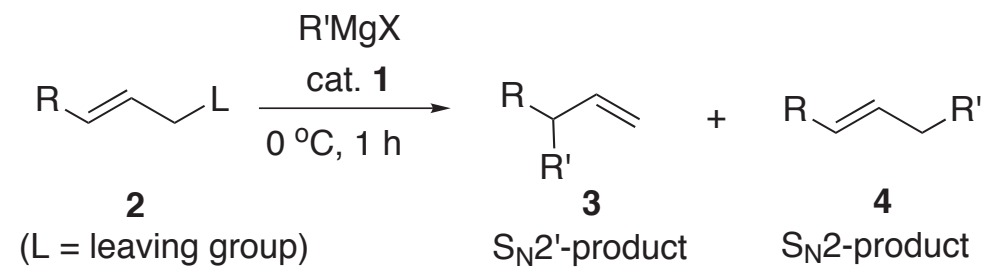

As revealed from the additional results shown in Table 1, which were obtained by the reactions of cinnamyl carbonate $\mathbf{2 a}$ or chloride $\mathbf{2 b}$ with $i$-PrMgCl catalyzed by imidazolium carbene complex $\mathbf{1 a}$ and 4,5-dihydroimidazolium carbene complex 1c, $1 \mathbf{a}$ as well as 1c could efficiently catalyze the reaction in a highly $\mathrm{S}_{\mathrm{N}} 2$ '-selective way (entries 1 and 2). It was observed again that the reaction of allyl chloride in THF proceeded $\mathrm{S}_{\mathrm{N}} 2$ '-selectively as well as that in ether but allyl carbonate gave mainly $\mathrm{S}_{\mathrm{N}}$ 2-product in THF (entries 1 and 3-5). It was noteworthy that the amount of the NHC-CuCl complex could be reduced to $0.001 \mathrm{~mol} \%$ and the catalysis recorded a high TON (10 $)$ (entry 7). 
Table $1^{a}$ 1-Catalyzed Substitution of $2(\mathrm{R}=\mathrm{Ph})$ with $i-\mathrm{PrMgCl}$

\begin{tabular}{|c|c|c|c|c|c|}
\hline entry & $2(\mathrm{R}=\mathrm{Ph})$ & $\begin{array}{c}1 \\
(\mathrm{~mol} \%)\end{array}$ & solvent & $3: 4^{b}$ & total yield \\
\hline 1 & 2a: $\mathrm{L}=\mathrm{OCO}_{2} \mathrm{Et}$ & $1 a(1)$ & $\mathrm{Et}_{2} \mathrm{O}$ & $98: 2$ & quant. \\
\hline 2 & $2 a$ & $1 c(1)$ & $\mathrm{Et}_{2} \mathrm{O}$ & $98: 2$ & quant. \\
\hline 3 & $2 a$ & $1 a(1)$ & THF & $8: 92$ & $21 \%^{c}$ \\
\hline 4 & 2b: $L=C l$ & $1 a(1)$ & $\mathrm{Et}_{2} \mathrm{O}$ & $96: 4$ & quant. \\
\hline 5 & $2 b$ & $1 a(1)$ & THF & $89: 11$ & quant. \\
\hline 6 & $2 b$ & $1 \mathrm{a}(0.1)$ & $\mathrm{Et}_{2} \mathrm{O}$ & $96: 4$ & quant. \\
\hline $7^{d}$ & $2 b$ & $1 \mathrm{a}(0.001)$ & $\mathrm{Et}_{2} \mathrm{O}$ & $92: 8$ & quant. $(98 \%)^{e}$ \\
\hline \multicolumn{6}{|c|}{$\begin{array}{l}{ }^{a} \mathrm{~A} \text { mixture of } 1(0.001 \sim 1 \mathrm{~mol} \%), i-\mathrm{PrMgCl}(1.5 \text { equiv., } 0.7 \sim 1.3 \mathrm{M} \text { in } \\
\text { ether) and } 2 \mathrm{a}\left(1.0 \text { equiv.) was stirred for } 1 \mathrm{~h} \text { at } 0^{\circ} \mathrm{C} \text {, unless }\right. \\
\text { otherwise indicated. }{ }^{b} \text { Determined by } 500 \text { or } 600 \mathrm{MHz}{ }^{1} \mathrm{H} \text { NMR } \\
\text { analysis of the crude mixture. }{ }^{c} 78 \% \text { of } 2 \mathrm{a} \text { was recovered. }{ }^{d} \mathrm{The} \\
\text { reaction was performed for } 10 \mathrm{~h} \text { at } 0^{\circ} \mathrm{C} \text {. }{ }^{e} \text { Isolated by column } \\
\text { chromatography. }\end{array}$} \\
\hline
\end{tabular}

\subsection{Comparison with Stoichiometric Reactions}

To discuss the active species in the catalysis, we carried out the corresponding stoichiometric reactions and compared the results with those in the catalytic reactions (Table 2). Thus, the reaction of allylic carbonate $\mathbf{2 a}$ and $i$-PrMgCl with a stoichiometric amount of $\mathbf{1}$ (entry 2) was found to be much slower than that with a catalytic amount of $\mathbf{2}$ (entry 1 ) or resulted in no reaction (entry 5 ). On the other hand, a mixture of one equiv of $\mathbf{1}$ and two equiv of $i$-PrMgCl could convert $\mathbf{2}$ to $\mathbf{3}$ and $\mathbf{4}$ very quickly with a high regioselectivity (entries 3 and 6).

Table 2 Reaction of $\mathbf{2 a}$ with $i$-PrMgCl under various conditions

\begin{tabular}{|c|c|c|c|c|c|c|}
\hline \multirow{2}{*}{ entry } & \multirow{2}{*}{1 (equiv.) } & \multirow{2}{*}{$\begin{array}{c}i \text {-PrMgCl } \\
\text { (equiv.) }\end{array}$} & \multirow{2}{*}{ conditions } & \multicolumn{2}{|c|}{ product, $\%$} & \multirow{2}{*}{ recovered $\mathbf{2 a}$} \\
\hline & & & & 3 & 4 & \\
\hline 1 & $1 a(0.01)$ & (1.5) & $0^{\circ} \mathrm{C}, 30 \mathrm{~min}$ & 98 & 2 & 0 \\
\hline 2 & $1 \mathbf{a}(1.5)$ & (1.3) & $0^{\circ} \mathrm{C}, 12 \mathrm{~h}$ & 13 & $<1$ & 86 \\
\hline 3 & $1 \mathrm{a}(1.3)$ & (2.6) & $0^{\circ} \mathrm{C}, 5 \mathrm{~min}$ & 93 & 5 & 2 \\
\hline 4 & $1 c(0.01)$ & (1.3) & $0^{\circ} \mathrm{C}, 15 \mathrm{~min}$ & 98 & 2 & 0 \\
\hline 5 & $1 c(1.5)$ & (1.3) & $0^{\circ} \mathrm{C}, 24 \mathrm{~h}$ & 0 & 0 & $\sim 100$ \\
\hline 6 & $1 c(1.3)$ & (2.6) & $0^{\circ} \mathrm{C}, 5 \mathrm{~min}$ & 86 & 4 & 0 \\
\hline
\end{tabular}

Based on these results, the major active catalyst in the present reaction can be postulated to be an ate-complex such as the type $\left[(\mathrm{NHC}) \mathrm{CuR}_{2}\right]^{-}(\mathrm{MgX})^{+}$(ii) but not a complex of the type $(\mathrm{NHC}) \mathrm{CuR}(\mathbf{i})$ [8]. 


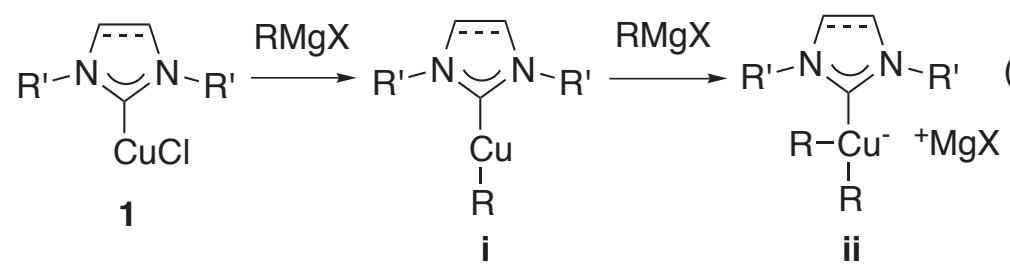

\subsection{Stereospecificity}

The results showed in Table 3, which were obtained by copper-catalyzed substitution reactions of cyclic allyl acetate $\mathbf{2 d}$, indicate their reaction course and stereospecificity. Thus, deuterated allylic acetate 2d [9], which was prepared from carvone by reduction with $\mathrm{LiAlD}_{4}$ and the following acetylation, was treated with 1.5 equiv of $i$-BuMgBr in the presence of $1 \mathrm{~mol} \%$ of copper salt. The reaction catalyzed by $\mathrm{CuCl}$ or $\mathrm{CuCN}$ afforded mainly an $\mathrm{S}_{\mathrm{N}} 2$-product and it was found that minor $\mathrm{S}_{\mathrm{N}} 2$ ' reaction proceeded in an anti fashion (entries 3 and 4). The 1b-catalyzed reaction "in THF" gave similar results and the reaction was found to be relatively slow (entry 2). Meanwhile, it was noteworthy that the 1b-catalyzed reaction "in ether" gave $\mathrm{S}_{\mathrm{N}} 2$ '-products predominantly and the reaction proceeded in a syn pathway mainly (entry 1). These results suggest that coordination between the acetoxy group and a metal atom present in an active species might affect the $\mathbf{1 b}$-catalyzed reaction in ether (Figure 2) [10].
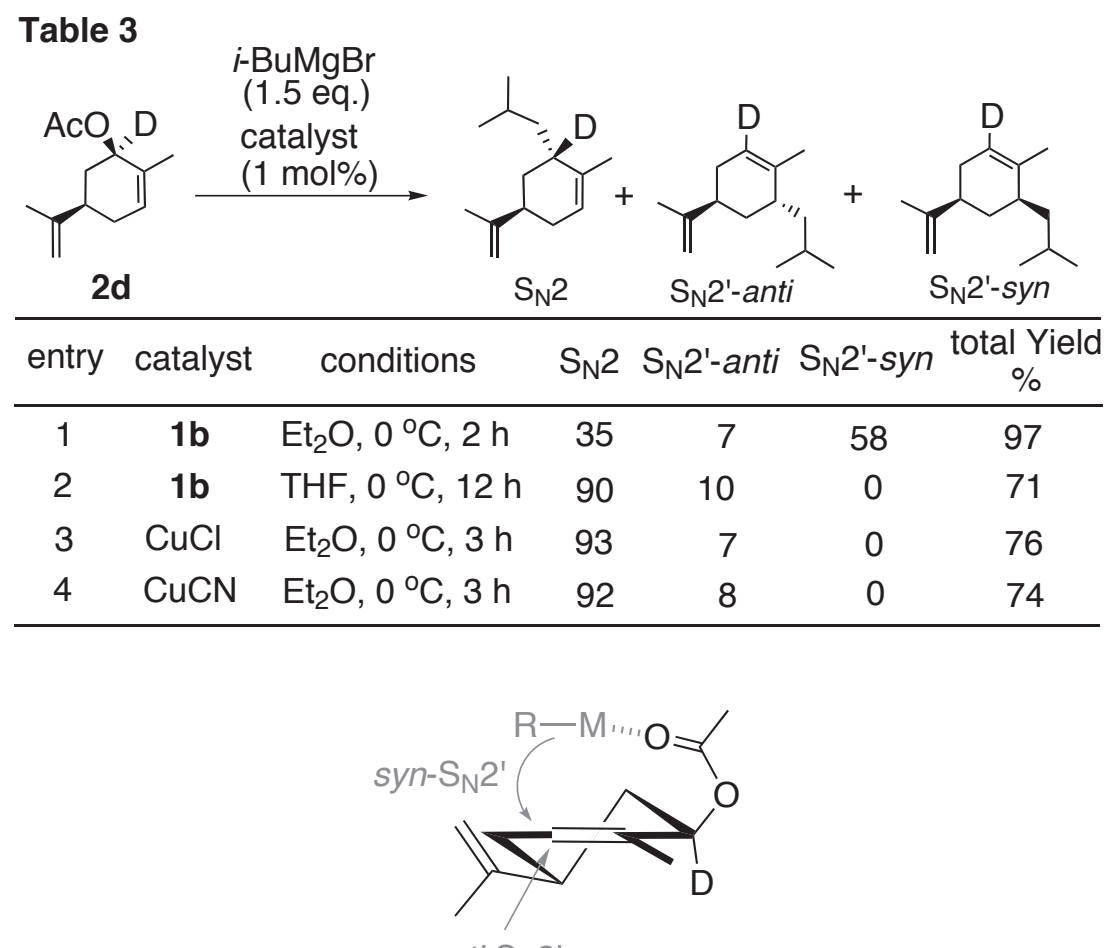

$\operatorname{anti-S}_{\mathrm{N}} 2^{1}$

Figure 2 
Table 4 shows the results of the substitution reaction of 4-(silyloxy)-but-2-en-1-ol derivatives with $n-\mathrm{C}_{6} \mathrm{H}_{13} \mathrm{MgBr}$ using $C_{2}$-chiral NHC-CuCl 1d, 1 e, $1 \mathbf{f}$ and $\mathbf{1 g}$ as a catalyst precursor. Because the complexes 1d, 1e, 1f and $\mathbf{1 g}$ in their solid state were somewhat unstable toward moisture and/or air, the THF solution containing 1d-f was respectively prepared from the corresponding imidazolium salt, $t$ - $\mathrm{BuONa}$ and $\mathrm{CuCl}[6 \mathrm{a}]$ and the resulting solution was stored under Ar. The solution was charged into the reaction vessel and THF was removed under reduced pressure prior to use. As revealed from the results shown in entries 1-5, enantiomeric excess (e.e.) of the $S_{N} 2$ ' product was highly dependent on the nature of the leaving group and the coordinative moiety such as acetoxy and 2-pyridyloxy groups gave better e.e. The complex with sterically demanding $N$-substituents (1e) or 4,5-dihydroimidazolium carbene- $\mathrm{CuCl}$ (1f) gave better e.e. than that obtained with 1d (entry 1 vs. entries 6 and 7). Inversion of the product configuration was observed when $(E)$-allylic substrates were used instead of $(Z)$-isomers (entries 11 and 12). The highest enantiomeric ratio of 85:15 was attained by the reaction of (Z)-2-pyridyl ether with catalyst $1 \mathbf{e}$ (entry 9 ). The fact that the reaction with conformationally rigid NHC-CuCl 19 with $(S, S)$-configuration gave the $\mathrm{S}_{\mathrm{N}} 2$ ' product with $(R)$-configuration (entry 10) suggests the conformation of $N$-substituents in the active catalysts derived from $\mathbf{1 d}, \mathbf{1 e}$ and $\mathbf{1 f}$, the $(R, R)$-isomers of which produced $(R)$-product predominantly (vide infra).

\begin{tabular}{|c|c|c|c|c|c|c|}
\hline \multicolumn{3}{|c|}{${\text { Table } 4^{a}}_{\mathrm{R}^{2}}$} & \multicolumn{2}{|c|}{$\begin{array}{c}n-\mathrm{C}_{6} \mathrm{H}_{13} \mathrm{MgBr} \\
\text { catalyst } \\
\underset{\text { ether, }-20^{\circ} \mathrm{C}}{20 \mathrm{~h}}\end{array}$} & \multirow{2}{*}{\multicolumn{2}{|c|}{$\frac{{ }_{n-\mathrm{C}_{6} \mathrm{H}_{13}}^{\mathrm{R}_{\mathrm{R}^{2}}^{1}}}{\begin{array}{l}\text { \% e.e.e. } \\
\text { (Config.) }\end{array} \mathrm{S}_{\mathrm{N}} 2^{\prime}: \mathrm{S}_{\mathrm{N}} 2}$}} \\
\hline entry & $\mathrm{R}^{1}$ & $R^{2}$ & OR & $\begin{array}{l}\text { catalyst } \\
(\mathrm{mol} \%)\end{array}$ & & \\
\hline 1 & $\mathrm{H}$ & $\mathrm{TBSOCH}_{2}$ & $\mathrm{OAc}$ & 1d (5) & $40(R)$ & $87: 13$ \\
\hline 2 & $\mathrm{H}$ & $\mathrm{TBSOCH}_{2}$ & $\mathrm{OCO}_{2} \mathrm{Et}$ & 1d (5) & $5(R)$ & $96: 4$ \\
\hline 3 & $\mathrm{H}$ & $\mathrm{TBSOCH}_{2}$ & $\mathrm{OP}(\mathrm{O})(\mathrm{OEt})_{2}$ & 1d (5) & $8(R)$ & $99: 1$ \\
\hline 4 & $\mathrm{H}$ & $\mathrm{TBSOCH}_{2}$ & $\mathrm{Cl}$ & $1 d(5)$ & $8(S)$ & $77: 23$ \\
\hline 5 & $\mathrm{H}$ & $\mathrm{TBSOCH}_{2}$ & O-(2-pyridyl) & $1 d(5)$ & $36(R)$ & ) $91: 9$ \\
\hline 6 & $\mathrm{H}$ & $\mathrm{TBSOCH}_{2}$ & OAC & $1 f(1)$ & $52(R)$ & ) $49: 51$ \\
\hline 7 & $\mathrm{H}$ & $\mathrm{TBSOCH}_{2}$ & $\mathrm{OAc}$ & $1 e(5)$ & $60(R)$ & $95: 5$ \\
\hline 8 & $\mathrm{H}$ & $\mathrm{TBSOCH}_{2}$ & $\mathrm{OC}(\mathrm{O}) \mathrm{NMe}_{2}$ & $1 e(5)$ & $55(R)$ & ) 99:1 \\
\hline 9 & $\mathrm{H}$ & $\mathrm{TBSOCH}_{2}$ & O-(2-pyridyl) & $1 e(5)$ & $70(R)$ & $98: 2$ \\
\hline 10 & $\mathrm{H}$ & $\mathrm{TBSOCH}_{2}$ & O-(2-pyridyl) & $\lg (1)$ & $50(R)$ & $98: 2$ \\
\hline 11 & $\mathrm{TBSOCH}_{2}$ & $2 \quad \mathrm{H}$ & OAc & $1 e(5)$ & $38(S)$ & ) $97: 3$ \\
\hline 12 & $\mathrm{TBSOCH}_{2}$ & $\mathrm{H}$ & O-(2-pyridyl) & $1 e(5)$ & $60(S)$ & $86: 14$ \\
\hline
\end{tabular}

\subsection{Proposing Transition Structure}

Although elucidation of the origin of the regioselectivity of the reaction remains difficult at this time, the results of the reactions with a stoichiometric amount of $\mathbf{1}$, the solvent effect and the effect of 
the coordinative nature of the leaving groups on regioselectivity, stereospecificity and enantioselectivity observed here suggest reaction mechanism as follows: The reaction might involve an ate-complex such as the type $\left[(\mathrm{NHC}) \mathrm{CuR}_{2}\right]^{-}(\mathrm{MgX})^{+}$as an active species which could be generated via the $(\mathrm{NHC}) \mathrm{CuR}$ complex (eq 2). The generated ate complex would react with the allylic substrate through the seven-membered cyclic structure (a) shown in Figure 3 which consists of $\pi$-complexation between the $\mathrm{Cu}$ atom and the carbon-carbon double bond of the substrate and the coordination between the leaving group and ${ }^{+} \mathrm{MgX}$ counter cation [10]. Use of THF instead of diethyl ether as a solvent may inhibit the coordination to retard the reaction and cause change of the regioselectivity.

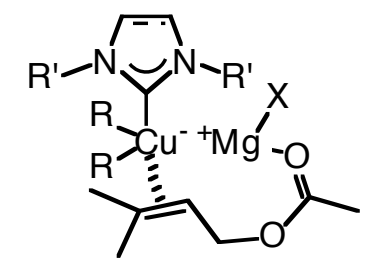

(a)

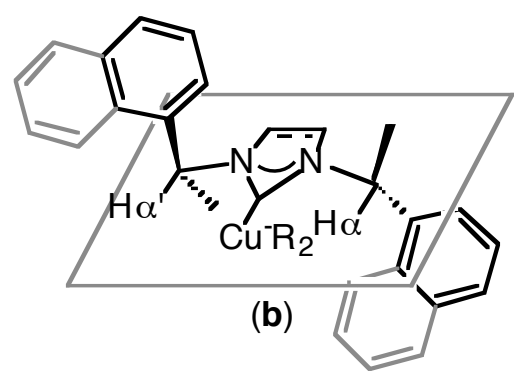

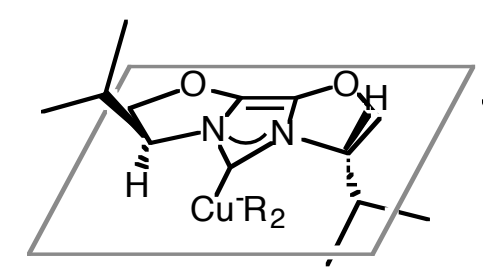

(c)

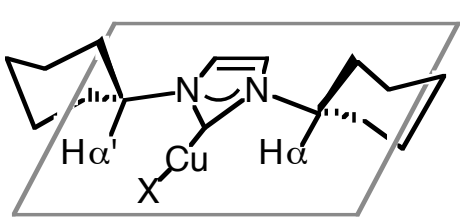

(d)

Figure 3

To discuss the enantioselection with 1d-f, conformation of their 1-arylethyl side-chain in the active species is important and comparison of the results of the $\mathbf{1 d - f}$ catalyzed reactions with those with $\mathbf{1 g}$ suggest that their active structure would be as (b) shown in Figure 3. Thus, the aryl moieties present in complexes (b) derived from 1d-f with the $R, R$-configuration should occupy the same quadrants around an imidazolium carbene- $\mathrm{Cu}$ axis as those which two $i$-Pr groups do in the rigid complex (c) derived from $1 \mathrm{~g}$ with $S, S$-configuration. In such conformation shown as (b) two hydrogen atoms $\mathrm{H} \alpha$ and $\mathrm{H}^{\prime}$ ' locate around sterically hindered $\mathrm{Cu}$ atom similarly to the conformation of the side chain in the solid state structure reported for 1,3-bis(cyclohexyl)imidazolin-2-ylidene copper chloride (d) [6d].

These findings and the discussion described here will support further study for development of $\mathrm{NHC}-\mathrm{CuCl}$ complexes giving better enantioselectivity of the present allylic substitution reaction and development of other reactions catalyzed by $\mathrm{NHC}-\mathrm{CuCl}$. Investigation along this line is under way in our laboratories. 


\section{Experimental}

\subsection{General}

NMR spectra were recorded in $\mathrm{CDCl}_{3}$ at 600,500 and $270 \mathrm{MHz}$ for ${ }^{1} \mathrm{H}$ and 150,125 and $67.5 \mathrm{MHz}$ for ${ }^{13} \mathrm{C}$, respectively, on JEOL JNM-ECA600, 500 and -EX270 spectrometers. Chemical shifts are reported in parts per million $(\mathrm{ppm}, \delta)$ relative to $\mathrm{Me}_{4} \mathrm{Si}(\delta 0.00)$ or residual $\mathrm{CHCl}_{3}\left(\delta 7.26\right.$ for ${ }^{1} \mathrm{H}$ and $\delta$ 77.0 for ${ }^{13} \mathrm{C}$ ). IR spectra were recorded on an FT-IR spectrometer (HITACHI 270-30) and are reported in wave numbers $\left(\mathrm{cm}^{-1}\right)$. All reactions sensitive to oxygen and/or moisture were performed under an argon atmosphere. Dry solvents (THF and ethyl ether) were purchased from Kanto Chemicals. Grignard reagents were prepared from magnesium turnings and the corresponding organic halide in ethyl ether or THF, titrated by an acid-base titration using aqueous $1.0 \mathrm{M} \mathrm{HCl}$ and $0.5 \mathrm{M} \mathrm{NaOH}$, and stored under argon. Imidazolium salts, i.e., 1,3-bis(2,4,6-trimethylphenyl)-3H-imidazol-1-ium chloride [4c,12], 1,3-bis(2,4,6-trimethylphenyl)-4,5-dihydro-3H-imidazol-1-ium chloride [13], $(R, R)$-1,3-bis(1-phenylethyl)-3H-imidazol-1-ium chloride [5c,14], $(R, R)$-1,3-bis[1-(1-naphtyl)ethyl]-3H-imidazol-1-ium chloride [5c,14], and $(S, S)$-1,6-diisopropyl-1,2,5,6-tetrahydro-3,4-dioxa-7a-aza-6a-azonia-cyclopenta[a]pentalene triflate [15] were prepared from the corresponding amines according to the reported procedures. Other chemicals are commercially available, unless otherwise indicated, and were used as received.

\subsection{Preparation of $\mathrm{NHC}-\mathrm{CuCl}$ Complexes 1a-c}

1,3-Bis(2,6-dimethyl-phenyl)imidazolin-2-ylidene copper chloride (1b): To a mixture of 1,3-bis(2,6-dimethylphenyl)-3H-imidazol-1-ium chloride (313 mg, $1.0 \mathrm{mmol}$ ), $\mathrm{CuCl}$ (89 mg, 0.90 $\mathrm{mmol})$ and $t$-BuONa $(96 \mathrm{mg}, 1.0 \mathrm{mmol})$ was added THF $(7 \mathrm{~mL})$. The resulting suspension was stirred for $6 \mathrm{~h}$ at room temperature and filtered through a pad of Celite. The filtrate was concentrated in vacuo to give $\mathbf{1 b}\left(264 \mathrm{mg}, 78 \%\right.$ yield) as a red-brown powder. $\mathrm{Mp} .268{ }^{\circ} \mathrm{C} ;{ }^{1} \mathrm{H} \mathrm{NMR}\left(\mathrm{CDCl}_{3}, 500 \mathrm{MHz}\right) \delta$ $7.31(\mathrm{t}, J=7.5,2 \mathrm{H}), 7.21(\mathrm{~d}, J=8.0,4 \mathrm{H}), 7.10(\mathrm{~s}, 2 \mathrm{H}), 2.17(\mathrm{~s}, 12 \mathrm{H}) ;{ }^{13} \mathrm{C} \mathrm{NMR}\left(\mathrm{CDCl}_{3}, 125 \mathrm{MHz}\right) \delta$ 178.5, 137.4, 134.9, 129.6, 128.8, 122.1, 17.8; IR (neat) 3166, 1695, 1599, 1557, 1479, 1443, 1404, 1335, 1290, 1230, 1161, 1110, 1038, 948, 786, 735, 693, 609. Anal. Calcd. for $\mathrm{C}_{19} \mathrm{H}_{2} \mathrm{~N}_{2} \mathrm{OClCu}: \mathrm{C}$, 60.79; H, 5.37; N, 7.46. Found: C, 60.95; H, 5.54; N, 7.47.

1,3-Bis(2,4,6-trimethyl-phenyl)imidazolin-2-ylidene copper chloride (1a): ${ }^{1} \mathrm{H}$ NMR (500 MHz, $\left.\mathrm{CDCl}_{3}\right) \delta 7.06(\mathrm{~s}, 2 \mathrm{H}), 7.00(\mathrm{~s}, 4 \mathrm{H}), 2.34(\mathrm{~s}, 6 \mathrm{H}), 2.10(2,12 \mathrm{H}) ;{ }^{13} \mathrm{C} \mathrm{NMR}\left(125 \mathrm{MHz}, \mathrm{CDCl}_{3}\right) \delta 178.7$, 139.2, 134.9, 134.4, 129.3, 122.2, 21.1, 17.6; IR (KBr) 2914, 1485, 1400, 1234, 1076, 932, 862, 702 $\mathrm{cm}^{-1}$. Anal. Calcd. for $\mathrm{C}_{21} \mathrm{H}_{24} \mathrm{ClCuN}_{2}$ : C, 62.52; H, 6.00; N, 6.94. Found: C, 62.33; H, 6.16; N, 6.86. 
1,3-Bis(2,4,6-trimethyl-phenyl)imidazolidin-2-ylidene copper chloride (1c): The spectral data $\left({ }^{1} \mathrm{H}\right.$ and ${ }^{13} \mathrm{C}$ NMR) were in good agreement with those reported [6d]. Anal. Calcd. for $\mathrm{C}_{21} \mathrm{H}_{26} \mathrm{ClCuN}_{2}: \mathrm{C}$, 62.21; H, 6.46; N, 6.91. Found: C, 62.34; H, 6.16; N, 6.98.

\subsection{Allylic Substitution Reactions with Grignard Reagents Catalyzed by Imidazolium Carbene-CuX Complexes}

Reaction with 1 mol\% of $\mathrm{NHC}-\mathrm{CuCl}$ complexes 1: To a suspension of an imidazolium or 4,5-dihydroimidazolium carbene- $\mathrm{CuCl}$ complex $1(0.01 \mathrm{mmol}, 1 \mathrm{~mol} \%)$ in ether $(1 \mathrm{~mL})$ was added dropwise a solution of Grignard reagent $(1.5 \mathrm{mmol})$ at $0{ }^{\circ} \mathrm{C}$ and the resulting mixture was stirred for 15 min. To this was added dropwise a solution of allylic substrate $2(1.0 \mathrm{mmol})$ and the mixture was stirred for $1 \sim 2 \mathrm{~h}$. After confirming the completion of the reaction by TLC analysis, saturated aqueous $\mathrm{NH}_{4} \mathrm{Cl}$ was added. The mixture was extracted with hexanes $(2 \times 10 \mathrm{~mL})$ and the combined organic layers were washed with brine, dried over $\mathrm{MgSO}_{4}$, concentrated. The 500 or $600 \mathrm{MHz}{ }^{1} \mathrm{H}$ NMR analysis of the crude residue determined the regioselectivity. Chromatography on silica gel gave the substitution products. The following spectral data were recorded using a mixture of $\mathbf{3}$ and $\mathbf{4}$.

Reaction with 0.001 mol\% of NHC-CuCl complex $1 a$ : In a flask a THF solution of 1 a $(100 \mu \mathrm{L}$, $0.001 \mathrm{M}, 10^{-4} \mathrm{mmol}$ ) was charged and THF was removed in vacuo. Under Ar atmosphere to this were added ether $(1.5 \mathrm{~mL}), i-\mathrm{PrMgCl}(11.5 \mathrm{~mL}, 1.3 \mathrm{M}$ in ether, $15 \mathrm{mmol})$ and cinnamyl chloride $(1.39 \mathrm{~mL}$, $10 \mathrm{mmol}$ ) at $0{ }^{\circ} \mathrm{C}$. The mixture was stirred for $10 \mathrm{~h}$ at $0{ }^{\circ} \mathrm{C}$. The resulting white suspension was poured into aqueous $1 \mathrm{M} \mathrm{HCl}(30 \mathrm{~mL})$ and the mixture was extracted with ether $(2 \times 20 \mathrm{~mL})$, washed with saturated aqueous $\mathrm{NaHCO}_{3}(10 \mathrm{~mL})$, dried over $\mathrm{MgSO}_{4}$, and concentrated. The residue was passed through a short silica gel column with hexanes and concentrated to give a mixture of $\mathbf{3}$ and $\mathbf{4}(\mathrm{R}=\mathrm{Ph}$, $\mathrm{R}^{\prime}=i$-Pr, total $1.57 \mathrm{~g}, 98 \%$ yield) in a ratio of $92: 8$.

Spectral data of 4-methyl-3-phenyl-1-pentene obtained as the $\mathrm{S}_{\mathrm{N}} 2$ ' product by the reaction shown in Table 1 and 2 were identical with those reported [3e].

\subsection{Chiral Modified NHC-CuCl Complexes-Catalyzed Reactions}

THF solutions of compounds $1 \mathbf{d}-\mathbf{f}$ were prepared from the corresponding imidazolium salts, $t$-BuONa and $\mathrm{CuCl}$ in THF [6a]. The resulting mixture was filtered through a pad of Celite and the filtrate was stored under Ar because the corresponding complexes in their solid state were unstable toward moisture and/or air. The THF-solution containing 1d-1f, respectively, thus obtained was charged into the reaction vessel and THF was removed under reduced pressure prior to use. 
In a flask a THF solution (0.05 mmol) thus prepared was charged and THF was removed in vacuo. Under Ar atmosphere to this were added ether $(1.0 \mathrm{~mL}), i-\mathrm{PrMgCl}(1.15 \mathrm{~mL}, 1.3 \mathrm{M}$ in ether, $1.5 \mathrm{mmol})$ and 4-(silyloxy)-but-2-en-1-ol derivative $(1.0 \mathrm{mmol})$ at $-20{ }^{\circ} \mathrm{C}$. The mixture was stirred for $20 \mathrm{~h}$ at -20 ${ }^{\circ} \mathrm{C}$. To this was added saturated aqueous $\mathrm{NH}_{4} \mathrm{Cl}(10 \mathrm{~mL})$ and the mixture was extracted with ether $(2 \mathrm{x}$ $20 \mathrm{~mL})$, washed with saturated aqueous $\mathrm{NaHCO}_{3}(10 \mathrm{~mL})$, dried over $\mathrm{MgSO}_{4}$, and concentrated. The residue was passed through a short silica gel column with hexanes and concentrated to give tert-butyldimethyl(2-hexylbut-3-enyloxy)silane. Enantiomeric excess of the product was determined by conversion to the corresponding MTPA-esters [16] after protodesilylation and their ${ }^{1} \mathrm{H}$ NMR analysis. The absolute configuration was confirmed by conversion to the known 2-(tert-butyldimethyl-silyloxymethyl)octan-1-ol [17] by ozonolysis and the following reduction with $\mathrm{NaBH}_{4}$ and comparison of the optical rotation with that reported.

tert-Butyldimethyl(2-hexylbut-3-enyloxy)silane: ${ }^{1} \mathrm{H}$ NMR $\left(\mathrm{CDCl}_{3}, 270 \mathrm{MHz}\right) \delta 5.62$ (ddd, $J=8.4$, 9.7, $17.8 \mathrm{~Hz}, 1 \mathrm{H}), 4.97-5.07(\mathrm{~m}, 2 \mathrm{H}), 3.52(\mathrm{dd}, J=6.3,11.2 \mathrm{~Hz}, 1 \mathrm{H}), 3.49$ (dd, $J=6.3,11.2 \mathrm{~Hz}, 1 \mathrm{H})$, 2.07-2.23 (m, 1H), 1.10-1.60 (m, 10H), 0.89 (s, 9H), $0.88(\mathrm{t}, J=7.1 \mathrm{~Hz}, 3 \mathrm{H}), 0.07$ and 0.04 (2s, each $3 \mathrm{H}) ;{ }^{13} \mathrm{C} \mathrm{NMR}\left(\mathrm{CDCl}_{3}, 67.5 \mathrm{MHz}\right) \delta 140.6,115.2,66.7,31.8,30.8,29.4,27.0,26.0,22.7,18.4,14.1$, -5.3, -5.4; IR (neat) 3076, 2926, 2854, 1644, 1470, 1383, 1365, 1254, 1101, 1008, 942, 915, 837, 777 $\mathrm{cm}^{-1}$. Anal. Calcd. for $\mathrm{C}_{16} \mathrm{H}_{34} 0 \mathrm{Si} ; \mathrm{C}, 71.04 ; \mathrm{H}, 12.67$. Found; C, 70.64; H, 13.00 .

\section{References}

1. B. H. Lipshutz, S. Senguota, Org. React., 41 (1992) 135. R. M. Magid, Tetrahedron, 36 (1980) 1901. E. Erdik, Tetrahedron, 40 (1984) 641.

2. For organocopper chemistry, see: “Organocopper Reagents,” R. J. K. Talor Ed., Oxford University Press, Oxford (1994). B. H. Lipshutz, in “Organometallics in Synthesis,” M. Schlosser Ed., Wiley, Chichester (2002), p. 665. J.-E. Bäckvall, In “Modern Organocopper Chemistry,” N. Krause Ed., Wiley-VHC, Weinheim (2001), chapter 8. For allylic and propargylic substitution reactions with organocopper reagents, see: Y. Yamamoto, In Workbench Edition E 21 Volume4, "Stereoselective Synthesis," G. Helmchen, R. W. Hoffmann, J. Mulzer, E. Schaumann Eds., Thieme, Stuttgart and New York (1996).

3. Chiral copper complex-catalyzed enantioselective allylic substitution reactions: with Grignard reagents: (a) M. van Klaveren, E. S. M. Persson, A. del Villar, D. M. Grove, J.-E. Bäckvall, G. van Koten, Tetrahedron Lett., 36 (1995) 3059. (b) G. J. Meuzelaar, A. S. E. Karlström, M. van Klaveren, E. S. M. Persson, S. del Villar, G. van Koten, J.-E. Bäckvall, Tetrahedron, 56, (2000) 2895. (c) A. S. E. Karlström, F. F. Huerta, G. J. Meuzelaar, J.-E. Bäckvall, Synlett, (2001) 923. (d) A. Alexakis, C. Malan, L. Lea, C. Benhaim, X. Fournioux, Synlett, (2001) 927. (e) A. Alexakis, K. Croset, Org. Lett., 
4, (2002) 4147. (f) K. Tissot-Croset, A. Alexakis, Tetrahedron Lett., 45 (2004) 7375. (g) K. Tissot-Croset, D. Polet, S. Gille, C. Hawner, A. Alexakis, Synthesis, (2004) 2586. (h) B. Breit, D. Breuninger, Synthesis, (2005) 147. With dialkylzinc compounds, (i) F. Dübner, P. Knochel, Angew. Chem., Int. Ed., 38 (1999) 379. (j) F. Dübner, P. Knochel, Tetrahedron Lett., 41 (2000) 9233. (k) H. Malda, A. W. van Zijl, L. A. Arnold, B. L. Feringa, B, Org. Lett., 3 (2001) 1169. (1) C. A. Luchaco-Cullis, H. Mizutani, K. E. Muphy, A. H. Hoveyda, Angew. Chem., Int. Ed., 40 (2001) 1456. (m) S. Ongeri, U. Piarulli, M. Roux, C. Monti, C. Gennari, Helv. Chim. Acta, 85 (2002) 3388. (n) U. Piarulli, P. Daubos, C. Claverie, M. Roux, C. Gennari, Angew. Chem., Int. Ed., 42 (2003) 234. (o) . E. Murphy, A. H. Hoveyda, J. Am. Chem. Soc., 125 (2003) 4690. (p) K. Tissot-Croset, D. Polet, A. Alexakis, Angew. Chem., Int. Ed., 43 (2004) 2426. (q) M. A. Kacprzynski, A. H. Hoveyda, J. Am. Chem. Soc., 126 (2004) 10676. (r) A. O. Larsen, W. Leu, C. N. Oberhuber, J. E. Campbell, A. H. Hoveyda, J. Am. Chem. Soc., 126 (2004) 11130. (s) J. J. Van Veldhuizen, J. E. Campbell, R. E. Giudici, A. H. Hoveyda, J. Am. Chem. Soc., 127 (2005) 6877.

4. (a) H. W. Wanzlick, H.-J. Schonherr, Angew. Chem., Int. Ed., 7 (1968) 141. (b) K. Ofele, J. Organomet. Chem., 12 (1968) P42. (c) A. J. III. Arduengo, V. R. Diash, R. L. Harlow, M. Kline, J. Am. Chem. Soc., 114 (1992) 5530. (d) A. J. III. Arduengo, R. L. Harlow, M. Kline, J. Am. Chem. Soc., 113 (1991) 361. (e) W. A. Herrmann, C. Köcher, Angew. Chem., Int. Ed., 36 (1997) 2162. (f) A. J. III. Arduengo, Acc. Chem. Res., 32, (1999) 913. (g) D. Bourissou, O. Guerret, F. P. Gabbaï, G. Bertrand, Chem. Rev., 100 (2000) 39. (h) T. Weskamp, V. P. W. Böhm, W. A. Herrmann, J. Organomet. Chem., 600 (2000) 12. (i) W. A. Herrmann, Angew. Chem., Int. Ed., 41 (2002) 1290. (j) K. J. Cavell, D. S. McGuinness, Coord. Chem. Rev., 248 (2004) 671. (k) A. H. Cowley, J. Organomet. Chem., 617 (2001) 105. (l) D. Enders, H. Gielen, J. Organomet. Chem., 617 (2001) 70. (m) W. A. Herrmann, T. Weskamp, V. P. W. Böhm, Adv. Organomet. Chem., 48 (2001) 1. (n) L. Jafarpour, S. P. Nolan, Adv. Organomet. Chem., 46 (2001) 181.

5. Asymmetric conjugate addition reactions catalyzed by copper imidazolium carbene complexes: (a) F. Guillen, C. L. Winn, A. Alexakis, Tetrahedron:Asymmetry, 12 (2001) 2083. (b) P. K. Fraser, S. Woodward, Tetrahedron Lett., 42 (2001) 2747. (c) A. Alexakis, C. L. Winn, F. Guillen, J. Pytkowicz, S. Roland, P. Mangeney, Adv. Synth. Catal., 345 (2003) 345.

6. Other catalyses with copper imidazolium carbene complexes in organic synthesis: (a) V. Jurkauskas, J. P. Sadighi, S. L. Buchwald, Org. Lett., 5 (2003) 2417. (b) H, Kaur, F. K. Zinn, E. D. Stevens, S. P. Nolan, Organometallics, 23 (2004) 1157. (c) M. R. Fructos, T. R. Belderrain, M. Carmen Nicasio, S. P. Nolan, H. Kaur, M. Mar Díaz-Requejo, P. J. Pérez, J. Am. Chem. Soc., 126 (2004) 10846. (d) S. Díez-Gonález, H. Kaur, F. Kauer Zinn, E. D. Stevens, S. P. Nolan, J. Org. Chem., 70 (2005) 4784. References for recent structural studies of $N$-heterocyclic carbene copper complexes cited therein. See also ref $3 r$.

7. S. Tominaga, Y. Oi, T. Kato, D. K. An, S. Okamoto, Tetrahedron Lett., 45 (2004) 5585. 
8. Synthesis and structural study of $(\mathrm{NHC}) \mathrm{Cu}(\mathrm{I})$ methyl complex were reported: N. P. Mankad, T. G. Gray, D. S. Laitar, J. P. Sadighi, Organometallics, 23 (2004) 1191.

9. A. Ito, S. Ozawa, K. Oshima, S. Sakaki, H. Yamamoto, T. Hiyama, H. Nozaki, Bull. Chem. Soc. Jpn., 53 (1980) 2357.

10. Examples of $s y n-\mathrm{S}_{\mathrm{N}} 2$ ' allylic substitution reactions with organocopper reagents: C. Gallina, Tetrahedron Lett., 23 (1982) 3093. For directing leaving groups and their effects, see: B. Breit, P. Demel, C. Studte, Angew. Chem., Int. Ed., 43 (2004) 3786. A. Alexakis, Pure and Appl. Chem., 64 (1992) 387. I. Fleming, D. Higgins, N. J. Lawrence and A. P. Thomas, J. Chem. Soc. Perkin Trans. 1, (1992) 3331. See also references 1 and 2.

11. For examples of chiral NHC ligands in metal-catalyzed asymmetric synthesis, see refs $5,3 \mathrm{r}$ and $3 \mathrm{~s}$ and references cited therein. See also C. Song, C. Ma, Y. Ma, W. Feng, S. Ma, Q. Chaiand, M. B. Andrus, Tetrahedron Lett., 46 (2005) 3241.

12. A. J. III. Arduengo, US Patent 5,077,414, 1991.

13. A. W. Waltman, R. H. Grubbs, Organometallics, 23 (2004) 3105.

14. Y. Sato, T. Yoshino, M. Mori, Org. Lett., 5 (2003) 31. V. P. W. Bohm, T. Weskamp, C. W. K. Gstottmayr, W. A. Herrmann, Angew. Chem., Int. Ed., 39 (2000) 1602. W. A. Herrmann, L. J. Goossen, G. R. J. Artus, C. Koecher, Organometallics, 16 (1997) 2472.

15. F. Glorius, G. Altenhoff, R. Goddard, C. Lehmann, Chem. Commun., (2002) 2704.

16. J. A. Dale, H. S. Mosher, J. Am. Chem. Soc., 95 (1971) 512.

17. M. K. Gurjar, P. Bhaket, Heterocycles, 53 (2000) 143. 


\section{Graphical Abstract}

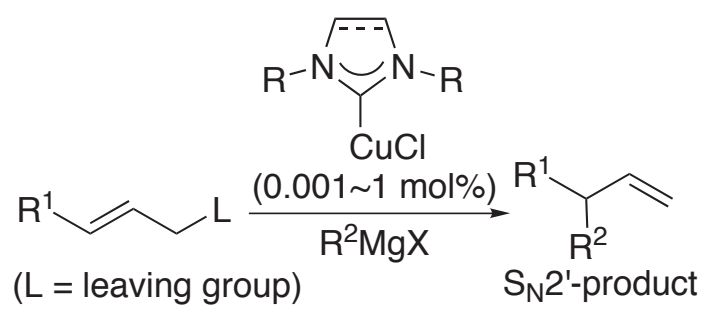

The ate-type complex(es) such as [(imidazolium carbene)-CuR $]_{2}^{-}(\mathrm{MgX})^{+}$was postulated as an active species. 